\title{
INVESTIGATION OF SETTING TIME AND FLOWABILITY OF GEOPOLYMER MORTAR USING LOCAL INDUSTRY AND AGRICULTURE WASTE AS PRECURSOR IN INDONESIA
}

\author{
Rahmad Afriansya ${ }^{1}$, ${ }^{*}$ Pinta Astuti ${ }^{2}$, Valda Salsabila Ratnadewati ${ }^{3}$, Julian Randisyah ${ }^{4}$, Tito Yoga \\ Ramadhona $^{5}$ and Evelyn Anabela Anisa ${ }^{6}$ \\ 1,2,3,4,5,6 Departement of Civil Engineering, Universitas Muhammadiyah Yogyakarta, Indonesia \\ *Corresponding Author, Received: 13 Sept. 2021, Revised: 08 Oct. 2021, Accepted: 17 Oct. 2021
}

\begin{abstract}
Geopolymer is a renewable construction material that reduces dependence on ordinary portland cement (OPC), where OPC manufacturing impacts carbon dioxide $\left(\mathrm{CO}_{2}\right)$ emissions. The main aspect of geopolymers being studied is the precursor of pozzolanic material, used as a cement substitute because it contains aluminosilicate (Si-Al). Polymerization occurs between the precursors, reacted by alkaline activator solution (AAS). Sodium hydroxide $(\mathrm{NaOH})$ and sodium silicate $\left(\mathrm{Na}_{2} \mathrm{SiO}_{3}\right)$ were used as AAS. In this study, local precursors from industrial waste and biomass were utilized. Fly ash was employed as a reference in the precursor by $5 \%$ - $10 \%$ substitution of glass powder, rice husk ash, bagasse ash, and palm shell ash. Moreover, $2 \%$ superplasticizer and $5 \%$ extra water were used to increase the flowability of fresh geopolymer. Tests were carried out on the setting time of paste, flow table, and compressive strength of geopolymer mortar. The tests were on the initial setting time of 25-75 minutes and the final setting time of 40-115 minutes. The setting time results revealed that the time of each substitution accelerated geopolymerization due to the substitution of precursors containing higher $\mathrm{CaO}$ and $\mathrm{SiO}_{2}$. Setting time and flowability/workability had a linear regression correlation $\left(\mathrm{R}^{2}\right)$ of 0.95 , with the flow table ranging from $180-250 \mathrm{~mm}$. The compressive strength ranged from $25.88-36.36 \mathrm{MPa}$ through a curing temperature of $70^{\circ} \mathrm{C}$ for 24 hours, followed by curing at ambient temperature for up to 28 days.
\end{abstract}

Keywords: Geopolymer, Precursor, Setting time, Flowability, Compressive strength

\section{INTRODUCTION}

Geopolymer is an innovation of concrete development, in which geopolymer concrete is designed without hydraulic cement as a binder. The binder of geopolymer uses powdered material as a precursor containing activated aluminosilicate with an alkali activator; thus, it becomes a geopolymer synthesis bond [1-3]. The geopolymer aims to reduce the impact of carbon dioxide $\left(\mathrm{CO}_{2}\right)$ emissions by up to $80 \%$, as well as dependence on the use of conventional cement [4]. Ordinary portland cement (OPC) is the dominant hydraulic binder in the material construction industry to date [5,6]. Chatam House [7] reported that there are 4 billion tons of global cement production annually, producing an estimated $8 \%$ of global $\mathrm{CO}_{2}$ emissions. The geopolymer material is necessary used to be a patch repair material of deteriorated reinforced concrete structures protected by cathodic protection due to its lower electrical resistivity than ordinary normal concrete $[8,9,10]$

Researchers have looked for alternative precursors from various sources such as waste from mining, industrial, agricultural, and others. In Indonesia, the potential of pozzolanic materials as geopolymer precursors is obtained through industrial and biomass waste. Coal fly ash is the potential primary precursor existing in Indonesia. It is due to the dependence of electricity production in Indonesia, which is still dependent on coal energy sources [11]. In 2020, the utilization of fly ash in Indonesia was only $0.9 \%$ of the total production of 7.8 million tons [12]. The latest regulations for the issuance of fly ash from hazardous and poisonous waste are expected to increase fly ash utilization in Indonesia [13]. Another industrial waste with the potential to be a substitute for precursors is glass powder as it contains high silica [14]. Additionally, as one of the world's agricultural countries, Indonesia has a lot of biomass waste of rice husks, palm shells, and bagasse, with a total of 15 million tons of waste annually [15].

The effect of the geopolymer can be determined by the constituent material and curing. The study of the chemical content of precursors in geopolymers affects the quality of geopolymers. The ratio of silicon dioxide $\left(\mathrm{SiO}_{2}\right)$ /aluminum oxide $\left(\mathrm{Al}_{2} \mathrm{O}_{3}\right)$ and calcium oxide $(\mathrm{CaO})$ will affect the geopolymer setting time. ratio $\mathrm{SiO}_{2} / \mathrm{Al}_{2} \mathrm{O}_{3}$ accelerates initial and final setting time $[16,17]$. Furthermore, the alkaline activator solution (AAS) influences flowability, setting time, and strength. The dominant ASS used in geopolymer research is sodium hydroxide $(\mathrm{NaOH})$ and sodium silicate $\left(\mathrm{Na}_{2} \mathrm{SiO}_{3}\right)$. Malkawi et al. [18] have tested the effect of concentration of $\mathrm{NaOH}(8,10$, and 12 molarity), with variations in the ratio of $\mathrm{Na}_{2} \mathrm{SiO}_{3} / \mathrm{NaOH}$ from 
1 to 2.5. Increasing the $\mathrm{NaOH}$ concentration and $\mathrm{Na}_{2} \mathrm{SiO}_{3} / \mathrm{NaOH}$ ratio decreased the flow diameter but was effective for the geopolymer strength. To achieve optimal strength, the geopolymerization formation process requires a temperature higher than room temperature. Zhang et al. [19] stated that curing geopolymer should be carried out at a temperature of $60-100{ }^{\circ} \mathrm{C}$ for $24-28$ hours. Panigrahi et al. [20] have studied the effect of curing temperature at $50,60,70$, and $80^{\circ} \mathrm{C}$ and discovered that curing at $70{ }^{\circ} \mathrm{C}$ for 24 hours had provided the optimum geopolymerization to achieve higher mechanical properties.

This experiment is intended to explore the feasibility of the geopolymer made with locally available precursors in Indonesia. In addition, superplasticizers and extra water were used to obtain high workability. This research aims to provide information on the setting time of paste, the flowability of fresh mortar, and the compressive strength of hardened mortar. The information would be useful and provide the groundwork for future investigation of waste precursors for geopolymers.

\section{RESEARCH SIGNIFICANCE}

Geopolymer is a novel construction material for future. Unfortunately, there is no official standard in the field of geopolymer research. Therefore, previous studies on geopolymer can be used as a reference regarding material selection and curing. The precursor variations were based primarily on fly ash and secondarily on the substitution of glass powder, rice hush ash, palm shell ash, and bagasse ash. Use of high alkali activator, superplasticizer, and extra water were kept constant. This investigation unveils optimal results of compressive strength and linear correlation between setting time and flowability. Hence, it could be a reference for further research on self-compacting/consolidating geopolymer.

\section{METHOD}

\subsection{Material Preparation}

The precursors used were local waste materials in Indonesia. These materials were obtained from industrial waste and biomass, comprising fly ash (FA), glass powder (GP), rice husk ash (RHA), palm shell ash (PSA), and bagasse ash (BA). Fly ash was obtained from the waste of PT. Tjiwi Kimia Indonesia, while the glass powder was from the processing of glass into powder. In addition, agricultural waste/biomass through the combustion process at a temperature of $600-900{ }^{\circ} \mathrm{C}$ was held for 2 hours, $600{ }^{\circ} \mathrm{C}$ for bagasse, $800{ }^{\circ} \mathrm{C}$ for rice husk, and $900{ }^{\circ} \mathrm{C}$ for palm shell. All precursors passed through a sieve mesh 200, and the physical and chemical properties of the different precursors are displayed in Table 1. In addition, Fig. 1 presents the $\mathrm{x}$-ray diffraction (XRD) pattern of precursors, where the peak is $20-30^{\circ} 2 \theta$ of amorphous quartz (Q).

The ratio of $\mathrm{NaOH} / \mathrm{Na}_{2} \mathrm{SiO}_{3}$ was 2.5 , and the concentration of $\mathrm{NaOH}$ was 12 molarity. It has been studied that $\mathrm{NaOH} / \mathrm{Na}_{2} \mathrm{SiO}_{3}$ was 2.5 , and $12 \mathrm{M}$ $\mathrm{NaOH}$ was the most optimal mixture of AAS to produce the most optimal compressive strength [20]. Moreover, $12 \mathrm{M} \mathrm{NaOH}$ was produced by mixing 480 grams of $\mathrm{NaOH}$ pellets dissolved with aqua dest/distilled water to reach one liter of solution. $\mathrm{NaOH}$ was prepared at least one day before the mixture. High $\mathrm{NaOH} / \mathrm{Na} 2 \mathrm{SiO} 3$ caused the viscosity of the liquid to become stiff, needing the use of superplasticizer (SP) and extra water to improve workability. The fine aggregate used was local sand sourced from the Progo River, Yogyakarta. Locally available river sand of 2.4 specific gravity, $2.27 \%$ fineness modulus, and 3,31\% moisture content were applied as fine aggregate

Table 1 Chemical and physical content of precursors

\begin{tabular}{lccccc} 
Content & FA & GP & RHA & PSA & BA \\
\hline $\mathrm{SiO}_{2}(\%)$ & 32 & 42.6 & 88.2 & 11 & 47.3 \\
$\mathrm{Al}_{2} \mathrm{O}_{3}(\%)$ & 13 & - & - & - & - \\
$\mathrm{Fe}_{2} \mathrm{O}_{3}(\%)$ & 27 & 1.2 & 0.9 & 19.1 & 14.7 \\
$\mathrm{CaO}(\%)$ & 19.5 & 8.34 & 1.3 & 38.3 & 18.6 \\
$\mathrm{MnO}(\%)$ & 0.28 & 0.08 & 0.31 & 0.27 & 0.54 \\
$\mathrm{~K} \mathrm{O}(\%)$ & 2.02 & 5,16 & 4.25 & 5.65 & 8.66 \\
Particle & $\leq 74$ & $\leq 74$ & $\leq 74$ & $\leq 74$ & $\leq 74$ \\
size $(\mu \mathrm{m})$ & & & & & \\
$\begin{array}{l}\text { Spefic } \\
\text { gravity }\end{array}$ & 2.53 & 2.34 & 2.14 & 2.0 & 1.94 \\
Color & gray & white & black & black & black \\
\hline
\end{tabular}

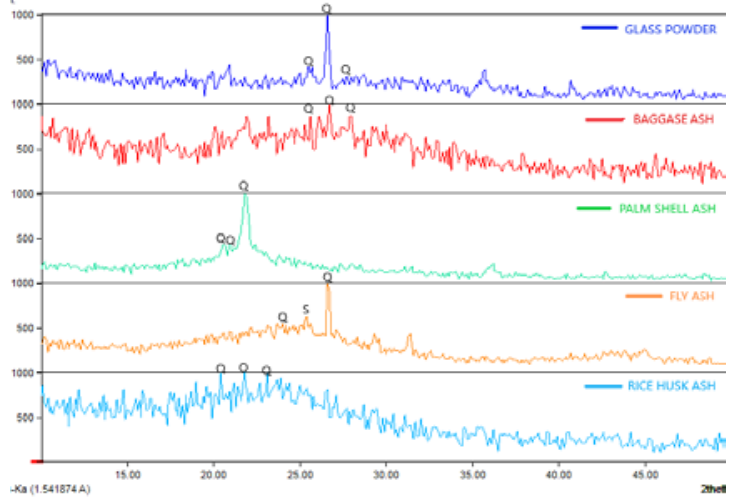

Fig. 1 XRD pattern of precursors

\subsection{Mix Proportion}

The primary precursor in this experiment was fly ash (containing aluminosilicate). Rice husk ash, palm shell ash, and powder glass were fixed at $10 \%$, while bagasse ash was fixed at $5 \%$ as fly ash replacement. In addition, superplasticizer was $2 \%$ 
and extra water was $5 \%$ by weight's precursor. The fine aggregate content was $60 \%$ of the volume Table 2 Mixture proportions $\left(\mathrm{kg} / \mathrm{m}^{3}\right)$

\begin{tabular}{|c|c|c|c|c|c|c|c|}
\hline \multirow{2}{*}{ Mixture Variation } & \multicolumn{2}{|c|}{ Precursor } & \multicolumn{2}{|c|}{ ASS } & \multirow{2}{*}{$\begin{array}{c}\text { Fine } \\
\text { aggregate }\end{array}$} & \multirow{2}{*}{ SP } & \multirow{2}{*}{$\begin{array}{l}\text { Extra } \\
\text { water }\end{array}$} \\
\hline & Primary & Subs & $\mathrm{Na}_{2} \mathrm{SiO}_{3}$ & $\mathrm{NaOH}$ & & & \\
\hline FA100\% (F) & 750 & 0 & 214.29 & 85.71 & 1200 & 15 & 37.5 \\
\hline FA95\%+GP10\% (FG) & 675 & 75 & 214.29 & 85.71 & 1200 & 15 & 37.5 \\
\hline FA90\%+PSA10\% (FP) & 675 & 75 & 214.29 & 85.71 & 1200 & 15 & 37.5 \\
\hline FA90\%+RHA10\% (FR) & 675 & 75 & 214.29 & 85.71 & 1200 & 15 & 37.5 \\
\hline FA90\%+BA5\% (FB) & 712.5 & 37.5 & 214.29 & 85.71 & 1200 & 15 & 37.5 \\
\hline
\end{tabular}

\subsection{Mixing, Casting, and Curing}

The mortar mixing process was carried out in several steps for 6 minutes using a planetary mixer. Initially, precursor and ASS were mixed for 2 minutes, then SP and extra water were added for a minute. Finally, the fine aggregate was added for 3 minutes. The fresh mortar mixture was then assessed for flowability. After performing the flowability test, the fresh mortar was placed in $5 \mathrm{~cm} \times 5 \mathrm{~cm} \times 5 \mathrm{~cm}$ of cube molds according to ASTM C109 [21]. After casting, each variation of the test samples was removed from the molds following the final setting time in Fig. 2. After that, the samples were cured in an oven at $70{ }^{\circ} \mathrm{C}$ for 24 hours. The samples were then wrapped in plastic and cured at ambient temperature for 28 days.

\subsection{Testing of Paste and Mortar Geopolymer}

\subsubsection{Setting time of paste}

The setting time test aimed to determine initial and final setting time as a determinant of the mold's release from the specimens according to ASTM C191 using Vicat at room temperature [22]. The variation of precursors in the setting time test is the same as that in Table 2. However, the constituent materials were only paste (precursors and ASS). Each variation consisted of 300 grams of precursor and 120 grams of ASS (ratio of $\mathrm{NaOH} / \mathrm{Na}_{2} \mathrm{SiO}_{3}$ was 2.5 and $12 \mathrm{M}$ of $\mathrm{NaOH}$ ).

\subsubsection{Flowability of fresh mortar}

The flowability test aimed to determine the percentage distribution of the fresh mortar used to achieve optimal conditions, as shown in Table 3, using the flow table test according to ASTM C1437-20 [23].

Table 3 Workability criteria [24]

\begin{tabular}{ccc}
\hline No & Flow Diamter $(\mathrm{mm})$ & Workability \\
\hline 1 & $>250$ & Very High \\
2 & $180-250$ & High \\
3 & $150-180$ & Moderate \\
4 & $120-150$ & Stiff \\
5 & $<120$ & Very stiff \\
\hline
\end{tabular}

mortar. The details of mixture proportions are depicted in Table 2 
It was discovered that $88 \%$ of $\mathrm{SiO}_{2}$ of $\mathrm{RHA}$ substitution influenced geopolymerization acceleration, whereas PSA and GP substitutions had inversely proportional $\mathrm{SiO}_{2}$ and $\mathrm{CaO}$ percentages, which were able to accelerate based on remarkably similar initial and final results. The fastest setting time was found in the BA substitution because both $\mathrm{SiO}_{2}$ and $\mathrm{CaO}$ were relatively high.

\subsection{Flowability}

Flow table test was used to measure flowability by flow diameter as an indicator of workability. Fig. 3 exhibits the effect of SP and extra water on diameter flow to reach high workability according to Table 3, and the flow diameter ranging $180-250$ mm. Each substitution of GP and agricultural ash (RHA, PSA, and BA) experienced a decrease in flow diameter. Agriculture ash had the lowest flow diameter due to the effect of water absorption. Saleh et al. [28] have tested RHA, PSA, and BA as cementitious materials and reported using more replacement agricultural waste that reduced flow diameter.

The aligned specific gravity for each substitution was a parameter that could only be considered a reference regarding flow reduction in the diameter of this study. Moreover, $1.94-2.53$ ranged in the specific gravity's precursors. However, further research is required on the flowability of geopolymer effect indicators of the precursors' physical and chemical characteristics.

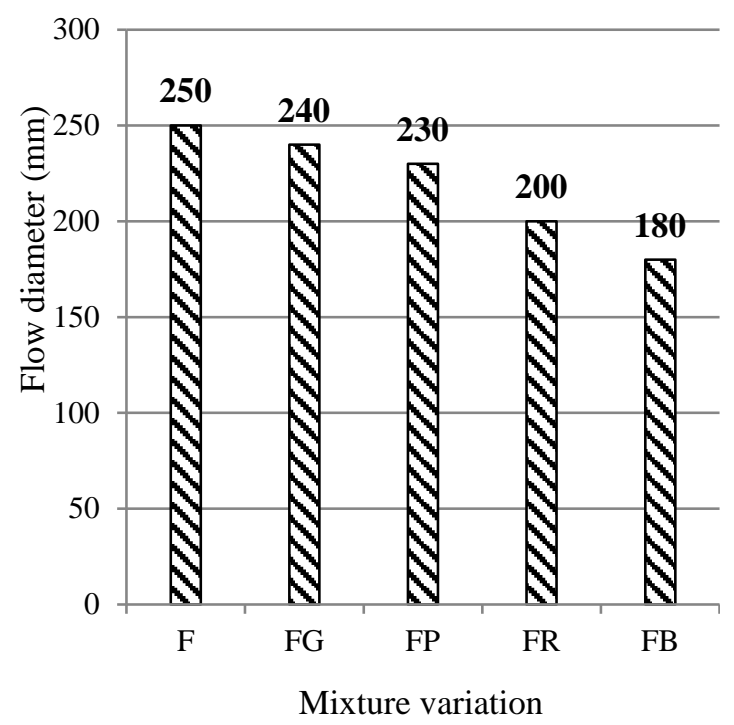

Fig. 3 Flowability of fresh geopolymer mortar

\subsection{Correlation of Setting Time and Flowability}

The setting time of geopolymer is related to its flowability/workability in geopolymer experiments. Longer setting time is associated with higher flow/slump in the geopolymer case [29-31]. Fig. 4 displays the correlation graph between setting time and flowability, revealing a regression equation $\left(\mathrm{R}^{2}\right)$ of 0.95

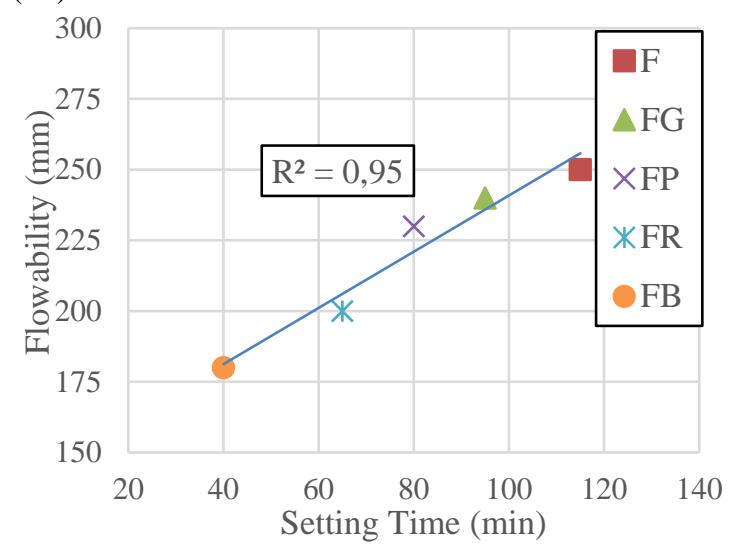

Fig. 4 The correlation of setting time-flowability

\subsection{Compressive Strength}

Fig. 5 presents the compressive strength of geopolymer mortar based on industrial and agricultural waste, ranging from 25.88 - 36.36 MPa. The primary reference mixture variation was 31.35 MPa of FA100\%. Based on Fig. 4, two results increase and decrease compressive strength. The highest compressive strength in this investigation was $36.36 \mathrm{MPa}$ by FA90\%+RHA10\%. The known parameter of increasing the compressive strength was by $88 \%$ of $\mathrm{SiO}_{2}$. $\mathrm{FA} 90 \%+\mathrm{PSA} 10 \%$ was the lowest compressive strength of $25.88 \mathrm{MPa}$ due to $11 \%$ of $\mathrm{SiO}_{2}$ of the PSA. Further research is required to achieve optimal compressive strength's performance of replacement of GP and PSA in a more specific range of $1 \%-9 \%$.

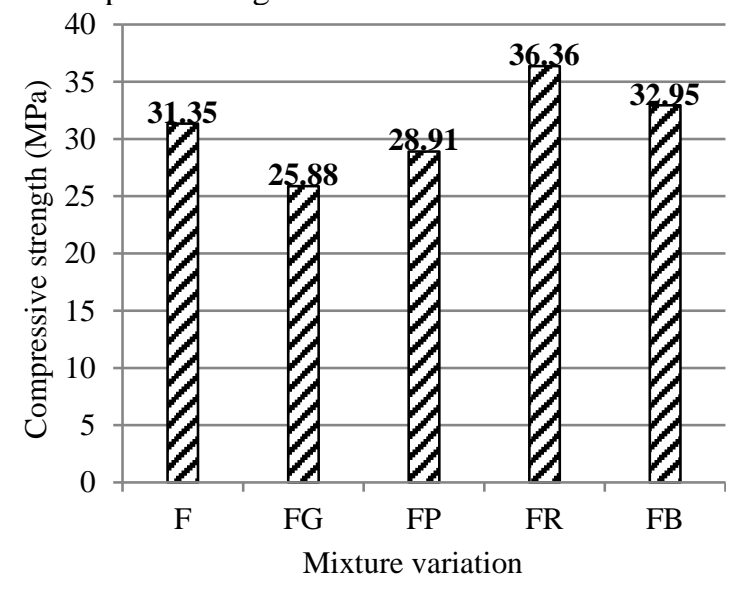

Fig. 5 Compressive strength of geopolymer mortar

\section{CONCLUSIONS}

Investigation on the utilization of industrial (fly ash and glass powder) and agricultural waste (rice husk, palm shell, and bagasse) has been carried out. Processing of agriculture waste into ash required 2 hours of combustion at $600-900{ }^{\circ} \mathrm{C}$. This 
experiment emphasizes fresh and hardened geopolymer. The use of $12 \mathrm{M} \mathrm{NaOH}$ and 2.5 of $\mathrm{NaOH} / \mathrm{Na}_{2} \mathrm{SiO}_{3}$ affected the stiffness of the fresh geopolymer. It is necessary to add a superplasticizer and extra water to increase flowability, although the impact of water in geopolymer will decrease the compressive strength. The following summarizes the results of five mixture variations in the study of setting time, flowability, and compressive strength in this paste and mortar geopolymer experiment.

1) Higher $\mathrm{SiO}_{2} / \mathrm{Al}_{2} \mathrm{O}_{3}$ and $\mathrm{CaO}$ of substitution precursors accelerated the geopolymerization of the paste based on the results of the initial and final setting time.

2) Using $2 \%$ superplasticizer and $5 \%$ extra water by weight of the precursor increased the flowability of fresh mortar in the flow diameter range of $180-250 \mathrm{~mm}$. It was classified as high workability.

3) Longer setting time was related to higher flow diameter. The $\mathrm{R}^{2}$ of the correlation between setting time and flowability was 0.95 .

4) The compressive strength of hardened mortar geopolymer ranged from 25.88 - $36.36 \mathrm{MPa}$, whereas the optimum was influenced by $10 \%$ rice husk ash due to its high $\mathrm{SiO}_{2}$ content.

The results of this investigation could be a reference for further research on selfcompacting/consolidating geopolymer concrete due to high workability.

\section{ACKNOWLEDGMENTS}

The authors would like to thank the Ministry of Education, Culture, Research, and Technology for financial support in this geopolymer experiment through Program Kreavitas Mahasiswa (PKM)Riset Eksakta.

\section{REFERENCE}

[1] Pathak, A., Kumar, S., and Jha, V. K., Development of building material from geopolymerization of construction and demolition waste (CDW), Transactions of the Indian ceramic society, Vol.73, Issue 2, 2014, pp.133-137.

[2] Chen, X., Meawad, A., and Struble, L. J., Method to stop geopolymer reaction, Journal of the American Ceramic Society, Vol.97, Issue 10, 2014, pp.3270-3275.

[3] Nazari, A., and Sanjayan, J. G. (2015)., Modelling of compressive strength of geopolymer paste, mortar and concrete by optimized support vector machine, Ceramics International, Vol.41, Issue 9, 2015, pp.1216412177.

[4] Valente, M., Sambucci, M., and Sibai, A., Geopolymers vs. Cement Matrix Materials:
How Nanofiller Can Help a Sustainability Approach for Smart Construction ApplicationsA Review. Nanomaterials, Vol.11, Issue 8, 2021. Pp. 1-34

[5] Wojtacha-Rychter, K., Kucharski, P., and Smolinski, A., Conventional and Alternative Sources of Thermal Energy in the Production of Cement-An Impact on $\mathrm{CO}_{2}$ Emission, Energies, Vol.14, Issue 6, 2021, pp.1-15.

[6] Gülşan, M. E., Alzeebaree, R., Rasheed, A. A., Niş, A., and Kurtoğlu, A. E., Development of fly ash/slag based self-compacting geopolymer concrete using nano-silica and steel fiber, Construction and building Materials, Vol.211, 2019, pp.271-283.

[7] Lehne Johanna and Preston Felix, Making Concrete Change Innovation in Low-carbon Cement and Concrete, Chatam House Report, 2018, pp.1-117.

[8] Astuti, P., Kamarulzaman, K., \& Hamada, H., Non-Destructive Investigation of A 44-YearOld RC Structure Exposed to Actual Marine Tidal Environments Using Electrochemical Methods, International Journal of Integrated Engineering, 13(3), 2021, pp.148-157.

[9] Astuti, P., Kamarulzaman, K., Rafdinal, R. S., Hamada, H., Sagawa, Y., \& Yamamoto, D., Influence of Rust Removal Process on The Effectiveness of Sacrificial Anode Cathodic Protection in Repair Concrete. In IOP Conference Series: Materials Science and Engineering, Vol. 849, No. 1, p. 012088, 2020.

[10] Astuti, P., Rafdinal, R. S., Hamada, H., Sagawa, Y., Yamamoto, D., \& Kamarulzaman, K., Effectiveness of rusted and non-rusted reinforcing bar protected by sacrificial anode cathodic protection in repaired patch concrete. In IOP Conference Series: Earth and Environmental Science, Vol. 366, No. 1, p. 012013, 2019.

[11] Handbook of Energi and Economic Statistics of Indonesia, Ministry of Energy and Mineral Resources Republic of Indonesia, 2020, pp.1105.

[12] Ekaputri, J. J., and Al Bari, M. S., The Comparison of Regulations on Fly Ash as a Hazardous Waste in Indonesia, Media Komunikasi Teknik Sipil, Vol.26, Issue 2, 2020, pp.150-162.

[13] Prasetiawan, T., The Controversy Of Removing Faba From The B3 Waste List. Info Singkat, Vol.13, Issue 7, 2021, pp.13-17

[14] Vafaei, M., and Allahverdi, A., High strength geopolymer binder based on waste-glass powder, Advanced Powder Technology, Vol.28, Issue 1, 2017, pp.215-222.

[15] Astuti, P., Afriansya, R., Anisa, E, A., Puspitasari, S, D., and Purnama, A, Y., The Potential Use Agriculture Pozzolan Waste as 
Cementitious Materials by Integrating with Biomass, In the Proceeding of 2nd ICITAMEE, Universitas Muhammadiyah Yogyakarta, Indonesia, August 25-26, 2021

[16] Chindaprasirt, P., De Silva, P., Sagoe-Crentsil, K., and Hanjitsuwan, S., Effect of $\mathrm{SiO} 2$ and $\mathrm{Al} 2 \mathrm{O} 3$ on the setting and hardening of high calcium fly ash-based geopolymer systems, Journal of Materials Science, Vol.47, Issue 12, 2012, pp.4876-4883.

[17] Phoo-ngernkham, T., Chindaprasirt, P., Sata, V., Hanjitsuwan, S., and Hatanaka, S., The effect of adding nano-SiO2 and nano-Al2O3 on properties of high calcium fly ash geopolymer cured at ambient temperature, Materials \& Design, Vol.55, 2014, pp.58-65.

[18] Malkawi, A. B., Nuruddin, M. F., Fauzi, A., Almattarneh, H., and Mohammed, B. S., Effects of alkaline solution on properties of the HCFA geopolymer mortars, Procedia engineering, Vol 148, 2016, pp.710-717.

[19] Zhang, P., Zheng, Y., Wang, K., and Zhang, J., A review on properties of fresh and hardened geopolymer mortar, Composites Part B: Engineering, Vol.152, 2018, pp.79-95.

[20] Panigrahi, M., Mohanty, S., Dash, R. R., \& Ganguly, R. I., Development of Novel Constructional Material from Industrial Solid Waste as Geopolymer. In IOP Conference Series: Materials Science and Engineering, Vol. 410, Issue 1, 2018, pp. 1-11

[21] ASTM-C109 Standard Test Method for Compressive Strength of Hydraulic Cement Mortar, Philadelphia, PA: American Society for Testing and Materials, 2015.

[22] ASTM-C191 Standard Test Methods for Time of Setting of Hydraulic Cement by Vicat Needle, Philadelphia, PA: American Society for Testing and Materials, 2010.

[23] ASTM-C1432-70 Standard Test Method for Flow of Hydraulic Cement Mortar, Philadelphia, PA: American Society for Testing and Materials, 2009.

[24]Ghosh, K., and Ghosh, P., Effect of $\mathrm{Na} 2 \mathrm{O} / \mathrm{Al} 2 \mathrm{O} 3, \mathrm{SiO} 2 / \mathrm{Al} 2 \mathrm{O} 3$ and $\mathrm{w} / \mathrm{b}$ ratio on setting time and workability of fly ash based geopolymer, International Journal of Engineering Research and Applications, Vol.2, Issue 4, 2012, pp.2142-2147.

[25] Wijaya, S. W., and Hardjito, D., Factors affecting the setting time of fly ash-based geopolymer, In Materials Science Forum, Vol. 841, 2016, pp. 90-97.

[26] BS EN 450-1, Fly Ash for Concrete, Definition, Specifications, and Conformity Criteria, 2012

[27] Chen, X., Sutrisno, A., and Struble, L. J., Effects of calcium on setting mechanism of metakaolin-based geopolymer, Journal of the American Ceramic Society, Vol.101, Issue 2, 2018, pp.957-968.

[28] Saleh, F., Prayuda, H., Monika, F., and Pratama, M. M. A., Characteristics Comparison on Mechanical Properties of Mortars using Agriculture Waste as a Cement Replacement Materials, In IOP Conference Series: Materials Science and Engineering, Vol. 650, Issue 1, 2019, pp.012039.

[29] Senff, L., Barbetta, P. A., Repette, W. L., Hotza, D., Paiva, H., Ferreira, V. M., and Labrincha, J. A., Mortar composition defined according to rheometer and flow table tests using factorial designed experiments, Construction and Building Materials, Vol.23, Issue 10, 2009, pp.3107-3111.

[30] Al-Majidi, M. H., Lampropoulos, A., Cundy, A., and Meikle, S., Development of geopolymer mortar under ambient temperature for in situ applications, Construction and Building Materials, Vol.120, 2016, pp.198-211.

[31] Huseien, G. F., Ismail, M., Khalid, N. H. A., Hussin, M. W., and Mirza, J., Compressive strength and microstructure of assorted wastes incorporated geopolymer mortars: Effect of solution molarity, Alexandria engineering journal, Vol.57, Issue 4, 2018, pp.3375-3386.

Copyright (C) Int. J. of GEOMATE All rights reserved, including making copies unless permission is obtained from the copyright proprietors. 